\title{
In vitro Differentiation Potential of Mesenchymal Stem Cells
}

\author{
Jeffrey M. Gimble ${ }^{a}$ Farshid Guilak ${ }^{b} \quad$ Mark E. Nuttall $^{c}$ Solomon Sathishkumar ${ }^{d} \quad$ Martin Vidal $^{\mathrm{e}}$ \\ Bruce A. Bunnell \\ a Stem Cell Biology Laboratory, Pennington Biomedical Research Center, Baton Rouge, LA, \\ ${ }^{b}$ Division of Orthopedic Research, Department of Surgery, Duke University Medical Center, Durham, NC, \\ ${ }^{c}$ Centocor, Johnson \& Johnson, Philadelphia, PA, USA \\ dChristian Medical College, Vellore, India \\ e Veterinary Clinical Sciences, School of Veterinary Medicine, Louisiana State University, Baton Rouge, LA, \\ ${ }^{f}$ Tulane University Primate Research Center, Covington, LA, USA
}

\section{Key Words}

Adipose-derived stem cells - Differentiation .

Mesenchymal stem cells

\section{Summary}

Mesenchymal stem cells (MSCs) represent a class of multipotent progenitor cells that have been isolated from multiple tissue sites. Of these, adipose tissue and bone marrow offer advantages in terms of access, abundance, and the extent of their documentation in the literature. This review focuses on the in vitro differentiation capability of cells derived from adult human tissue. Multiple, independent studies have demonstrated that MSCs can commit to mesodermal (adipocyte, chondrocyte, hematopoietic support, myocyte, osteoblast, tenocyte), ectodermal (epithelial, glial, neural), and endodermal (hepatocyte, islet cell) lineages. The limitations and promises of these studies in the context of tissue engineering are discussed.

\section{Introduction}

Seminal studies by Friedenstein [1] and coworkers [2], Owen [3], Tavassoli and Crosby [4] and others first identified what were initially referred to as bone marrow-derived 'mechanocytes' or stromal fibroblasts. These adherent cells displayed multipotent differentiation properties in vitro and in vivo. Fur-

\section{Schlüsselwörter}

Stammzellen aus Fettgewebe · Differenzierung . Mesenchymale Stammzellen

\section{Zusammenfassung}

Mesenchymale Stammzellen (MSCs) sind mulipotente Vorläuferzellen, die bisher aus verschiedenen Geweben isoliert wurden. Fettgewebe und Knochenmark gelten bezüglich des Gewebezugangs, der Stammzellmengen und ihrer Dokumentation in der wissenschaftlichen Literatur als besonders vorteilhaft. Schwerpunkt dieser Literaturzusammenfassung ist die In-vitro-Differenzierungsfähigkeit menschlicher Gewebezellen. Mehrere unabhängige Studien berichten, dass MSCs zur Differenzierung in sowohl mesenchymale (Adipozyten, Chondrozyten, hämatopoetischen Unterstützungzellen, Myozyten, Osteoblasten, Tenozyten) als auch ektodermale (epitheliale, gliale, and neurale Zellen) als auch endodermale (Hepatozyten, Pankreasinselzellen) Zelllinien fähig sind. Die Limitationen und Aussichten dieser Studien im Kontext von Tissue Engineering werden diskutiert.

thermore, after Friedenstein and Lalykina [5] discovered the presence of multipotent progenitor cells in thymus and other lymphoid tissues, independent groups went on to document their presence within tissues throughout the body (table 1). While research initially focused on the traditional mesodermal differentiation pathways associated with the bone marrow microenvironment (adipogenesis, chondrogenesis, osteogene-

\begin{tabular}{ll}
\hline KARGER & $\oplus$ 2008 S. Karger GmbH, Freiburg \\
Fax +49 7614520714 & Accessible online at: \\
$\begin{array}{l}\text { E-mail Information@Karger.de } \\
\text { www.karger.com }\end{array}$ & www.karger.com/tmh
\end{tabular}

\section{KARGER}

www.karger.com
Dr. Jeffrey M. Gimble

Stem Cell Biology Laboratory

Pennington Biomedical Research Cente

6400 Perkins Road, Baton Rouge, LA 70808, USA

E-mail gimblejm@pbrc.edu 
sis, and hematopoietic support [reviewed in 6-9], Caplan [10, 11] challenged existing dogma by introducing the concept of a 'mesenchymal stem cell' (MSC), a multipotent nonhematopoietic stem cell that is present in various adult tissues. He postulated that MSCs were present in the bone marrow and periosteum and were capable of differentiating along any mesodermal-associated pathway, including the myogenic and tendon lineages $[12,13]$. The use of the stem cell label remains controversial [14], and some investigators in the field have argued that the term should be modified to 'mesenchymal stromal cell' as an alternative [15]. Regardless of the nomenclature, there is a wealth of publications confirming the presence of a similar type of cell in various sites throughout the body and evaluating the differentiation potential of MSCs along the mesodermal, ectodermal and endodermal pathways.

In this review, we highlight selected studies on the in vitro differentiation potential of MSCs isolated from the two most promising sources of adult stem cells, adipose tissue and bone marrow. Furthermore, we have focused on studies using chemical agents and biological growth factors to induce MSC differentiation rather than genetic engineering approaches. While the latter methods are fascinating, they will require substantial development before meeting regulatory requirements. Finally, while numerous studies have been performed on MSCs using a variety of animal models, we have concentrated on the human literature for this clinical audience.

\section{Limitations and Promises of in vitro Analyses}

In vitro studies of MSC differentiation face several limitations. First, analyses of biochemical characteristics do not necessarily translate to in vivo applicability. Consequently, it is critical to show that MSC differentiation can be manipulated and directed in vivo in accordance with functional tissue engineering principles. Specifically, the MSCs must express the complex properties required of each tissue type and integrate into the existing structure in a seamless manner. Second, in vitro findings may not accurately mimic the signal transduction pathways controlling MSC development in vivo. Isolated analysis of a particular cytokine's effect on MSC differentiation in vitro may overlook important interactions with complementary or competing signaling pathways active under physiologic conditions. This may explain the discrepancies noted in the literature concerning the effects of bone morphogenetic proteins (BMPs) on adipogenesis and osteogenesis, for example [9]. Finally, it is always important to remember that observations with rodent MSCs, while providing excellent model systems, may not be predictive of the human response. Therefore, there is a continued need to focus on human MSC studies. In spite of these limitations, the study of MSC differentiation has revolutionized our understanding of cell biology. There is now a greater appreciation of the plasticity of adult cells, and the concept of an 'adult stem cell' is gaining greater recogni-
Table 1. Sources of MSCs: An overview of the literature

\begin{tabular}{ll}
\hline Tissue & Reference(s) \\
\hline Adipose & $\begin{array}{l}\text { human }[16,26,58,123-128] \\
\text { non-human }[129]\end{array}$ \\
Bone marrow & $\begin{array}{l}\text { human }[10,12,18,43,130-132] \\
\text { non-human }[1,2,129,133-137]\end{array}$ \\
Cartilage & human [138,139] \\
& non-human [129,140,141] \\
Dental pulp & {$[17,142-145]$} \\
Perichondrium & human [146] \\
& non-human [147,148] \\
Skeletal muscle & non-human [129,149-152] \\
Spleen & non-human [2,137] \\
Synovium & {$[153,154]$} \\
Tendon & human [155] \\
& non-human $[89,156]$ \\
\hline
\end{tabular}

tion and acceptance. It may be possible to 'reprogram' these adult stem cells using chemical or genetic approaches (see below). As such, they offer opportunities to explore questions in human biology that were formerly limited to pre-clinical animal models.

Human MSCs from adipose tissue and bone marrow have been characterized based on multiple criteria, including their surface immunophenotype, transcriptome, cytokine profile, and proteome [16-27]. While there is no consensus regarding a single surface antigen that identifies an MSC [28], a panel of several positive and negative markers has been identified [15]. The positive biomarkers include the CD73 (5' ectonucleotidase), CD90 (Thy1), and CD105 (endoglin) while the negative markers include those associated with hematopoietic lineages: myeloid (CD11b/14), lymphoid (CD19/ 79 $\alpha$ ), and related progeny (CD45, HLA-DR) [15]. Additional criteria for defining an MSC are plastic adherence and the capability of differentiating along the adipogenic, chondrogenic, and osteogenic lineage pathways [15]. Data from analyses of human adipose and bone marrow tissues suggest that a donor's age influences the frequency and/or proliferative rate of isolated MSCs [29, 30]. For further details on this topic, the reader is referred to the reviews entitled 'Mesenchymal Stem Cells: Tissue Origin, Isolation and Culture' [213] and 'Phenotypic Characterization of Mesenchymal Stem Cells from Various Tissues' [214] in this special issue of Transfusion Medicine And Hemotherapy.

\section{Mesodermal Lineage Potential}

\section{Hematopoietic Support}

In vivo, the MSCs are responsible for establishing what has been referred to as the microenvironmental milieu or stem cell niche necessary to support hematopoietic events [31-33]. This function has been associated specifically with the osteoblast lineage as supported by the localization of hematopoietic stem cells (HSCs) to the bone-lining surface of 


\begin{tabular}{|c|c|c|c|c|}
\hline \multirow{9}{*}{$\begin{array}{l}\text { Table 2. In vitro } \\
\text { mesenchymal lineage } \\
\text { differentiation poten- } \\
\text { tial: highlights from } \\
\text { the adipose- and } \\
\text { bone marrow-derived } \\
\text { MSCs literature }\end{array}$} & Lineage & Inductive factors & Adipose-derived MSCs & $\begin{array}{l}\text { Bone marrow-derived } \\
\text { MSCs }\end{array}$ \\
\hline & Adipocyte & $\begin{array}{l}\text { dexamethasone, indomethacin, } \\
\text { insulin, methylisobutylxanthine, } \\
\text { thiazolidinedione }\end{array}$ & {$[26,58,59,123]$} & {$[43,157,158]$} \\
\hline & Chondrocyte & $\begin{array}{l}\text { ascorbate, bone morphogenetic } \\
\text { protein } 6 \text {, dexamethasone, } \\
\text { transforming growth factor } \beta\end{array}$ & {$[26,45,70,123,125,159-162]$} & $\begin{array}{l}{[43,162,163]} \\
\text { non-human }[158,164]\end{array}$ \\
\hline & Endothelial & $\begin{array}{l}\text { ascorbate, epidermal growth } \\
\text { factor, fibroblast growth factor } 2 \text {, } \\
\text { vascular endothelial growth factor }\end{array}$ & {$[165-168]$} & {$[158,169]$} \\
\hline & Hematopoietic support & co-culture models & {$[22,36,170]$} & {$[171-173]$} \\
\hline & Muscle (skeletal) & $\begin{array}{l}\text { low serum concentration, horse } \\
\text { serum }\end{array}$ & {$[26,123,180-182]$} & non-human [183] \\
\hline & Muscle (smooth) & & {$[79,80]$} & {$[184,185]$} \\
\hline & Osteoblast & $\begin{array}{l}\text { ascorbate, bone morphogenetic } \\
\text { protein, dexamethasone, } \\
\text { 1,25 dihydroxy vitamin D3 }\end{array}$ & {$[26,123,124,126,186,187]$} & {$[43,158]$} \\
\hline & Tendon & mechanical stimuli & & non-human [188] \\
\hline
\end{tabular}

the marrow cavity $[31,32,34,35]$. The MSCs are capable of supporting the proliferation and differentiation of HSCs in vitro [6-9, 22, 34, 36]. The MSCs act through direct cell:cell interactions mediated by surface adhesion molecules, surface delivery of growth factors, and paracrine release of cytokines [33]. Classical studies have demonstrated that antibodies to the MSC or stromal surface adhesion molecules CD9, CD29 and CD44, among others, interfere with hematopoietic events [37-40]. Likewise, the MSCs or stromal cells have been found to express the cytokines IL-6 and IL-7, macrophage colony stimulating factor, stromal-derived factor 1 , and others that are associated with HSC proliferation, differentiation, and homing [22, 41, 42]. The adipose- and bone marrow-derived MSCs express a comparable, but not equivalent, surface immunophenotype based on flow cytometry [16, 25, 43-45], secrete a similar battery of cytokines [22, 46-48], and exhibit similar immunosuppressive properties [49-52]. Indeed, these immunosuppressive characteristics have led investigators to exciting studies exploring the utility of MSCs in the treatment of graft-versus-host disease and autoimmune conditions [53, 54]. These observations suggest that MSCs have potential clinical applications for in vitro expansion of HSCs and for in vivo enhancement and acceleration of HSC engraftment following transplantation.

\section{Adipogenesis}

The MSCs from adipose tissue and bone marrow can be induced to undergo adipogenesis by a number of stimuli (table 2). Direct comparisons indicate that cells isolated from adipose tissue are as good as or better than those from bone marrow with respect to adipogenesis (table 3). Among the most commonly employed agents are those that increase intracellular levels of cAMP, such as the phosphodiesterase inhibitor isobutylmethylxanthine (IBMX), a compound similar to the asthma therapeutic theophylline. Additional compounds are ligands for nuclear hormone receptors such as the glucocorticoid receptor (dexamethasone) and the peroxisome proliferator-activated receptor $\gamma(\operatorname{PPAR} \gamma$; e.g., rosiglitazone, the anti-diabetic insulin sensitizer Avandia $\left.{ }^{\mathrm{TM}}\right)$. The recent reports that diabetic patients on insulin sensitizers have an increased risk of fracture are entirely consistent with the mechanism of action of these nuclear receptor agonists driving adipogenesis at the expense of osteoblastogenesis [55]. The long-term use of PPAR $\gamma$ ligands could have important clinical consequences that may only present after longterm treatment caused by a reduction in total bone volume and a reduced time to fracture threshold. Finally, most adipogenic differentiation cocktails include insulin as well. Together, these agents convert the MSCs from fibroblast-like stromal cells to oval, neutral-lipid droplet-containing cells within a 3- to 9-day period in vitro. The process can be enhanced by the addition of linoleic, palmitic and oleic fatty acids [56]. The resulting differentiated MSCs display biochemical features characteristic of mature adipocytes, including the expression of gene markers (fatty acid-binding protein 4, lipoprotein lipase), secretion of adipokines (adiponectin, leptin), and lipolytic response to adrenergic agonists [43, 57-59]. 
Table 3. Studies comparing the differentiation potential of adipose MSCs (A) and bone marrow $\operatorname{MSCs}(\mathrm{B})^{\mathrm{a}}$

\begin{tabular}{llll}
\hline $\begin{array}{l}\text { Differentiation } \\
\text { potential }\end{array}$ & References & & \\
\cline { 2 - 4 } & adipogenesis & chondrogenesis & osteogenesis \\
\hline $\mathrm{A}>\mathrm{B}$ & {$[97,189-192]$} & {$[189]$} & {$[189]$} \\
$\mathrm{A}=\mathrm{B}$ & {$[26,123,193-198]$} & {$[26,123,194,197]$} & {$[26,123,193-199]$} \\
$\mathrm{B}>\mathrm{A}$ & & {$[97,162,190,191,193$,} & {$[97,190-192,202]$} \\
& & $196,200-203]$ & \\
\hline
\end{tabular}

${ }^{\mathrm{a}} \mathrm{A}$ total of 19 studies have compared the differentiation potential of stem cells from adipose tissue and bone marrow. Three of these studies have been done using animal tissue (rat [191], rabbit [201] and mice [199]). Out of the 16 studies involving human tissue, 4 were done on patient-matched comparisons $[97,162,193,200]$, and out of the 4 , only 2 studies compared adipogenic, osteogenic and chondrogenic differentiation potential of the stem cells, with different results as shown [97, 193]. Four out of the 16 studies on human tissue compared the differentiation potential of stem cells from adipose tissue and bone marrow, without making quantitative measurements [26, 123, 197, 198].

\section{Osteogenesis}

Likewise, the MSCs from adipose tissue and bone marrow can be induced to undergo osteogenesis (table 2). The majority of comparisons conclude that MSCs of bone marrow origin mineralize in vitro equally well as or better than those derived from adipose tissue (table 3). Continuous exposure of the MSCs to ligands for the glucocorticoid receptor (dexamethasone) and the vitamin D receptor (1,25 dihydroxy vitamin D3) together with ascorbic acid and $\beta$-glycerophosphate results in the mineralization of the extracellular matrix within a 3-week period. Alizarin red and von Kossa staining provide histochemical assays for the detection of calcium phosphate deposition. Additional biochemical assays include those for secreted osteocalcin and expression of the osteoblastic transcription factor, Cbfa1. These osteogenic responses can be further enhanced by the addition of the BMPs.

It has been hypothesized that MSC adipogenesis and osteogenesis are inversely related, i.e., that agents inducing adipogenesis do so at the expense of osteogenesis and vice versa [60-63]. Support for this argument comes from clinical studies, which have documented that the bone loss of osteoporosis is accompanied by increased marrow fat reserves. Furthermore, many agents promoting adipogenesis, such as the thiazolidinedione PPAR $\gamma$ ligands, inhibit osteogenesis [64, 65]. Likewise, compounds such as alendronate, classically viewed as an osteoclastic regulator, may have an anabolic effect on MSCs by promoting osteogenesis while simultaneously inhibiting adipogenesis [66]. Nevertheless, exceptions do exist. For example, despite their association with osteogenesis, the BMPs have been noted to promote adipogenesis in MSC models, depending on culture conditions [67-69]. Thus, the adipocyte/osteoblast lineage switch remains complex and merits further investigation using both in vitro and in vivo models.

\section{Chondrogenesis}

In the presence of ascorbate, dexamethasone, and transforming growth factor $\beta$, MSCs express a chondrogenic phenotype (table 2). In contrast to other lineages, chondrogenesis occurs most effectively when the MSCs are maintained in a threedimensional configuration (i.e. pellet or micromass culture or within a hydrogel such as agarose or alginate), rather than as an adherent two-dimensional culture plate. The majority of comparisons demonstrate that the chondrogenic potential of bone marrow-derived MSCs is equal to or superior to that of adipose-derived cells under these standard differentiation conditions (table 3); however, it should be noted that the differentiation cocktails were designed almost exclusively in studies using bone marrow MSCs, and increasing evidence indicates that there are significant differences between bone marrow- and adipose-derived MSCs. For example, more recent analyses have shown that adipose MSCs displayed enhanced chondrogenesis with the addition of BMP6 to the differentiation cocktail, with suppression of a hypertrophic phenotype as measured by the down-regulation of type X collagen [70]. Conversely, bone marrow MSCs exhibit increased expression of type $\mathrm{X}$ collagen and a hypertrophic phenotype in response to BMP6 [71]. The chondrogenic and osteogenic capacity of MSCs can be further manipulated by introducing the cells into synthetic scaffolds, such as polycaprolactone, prior to implantation in vivo. [72]. Ultimately, the MSCs need to synthesize the major cartilaginous proteins, collagen II and aggrecan, in quantities sufficient to regenerate damaged cartilage in an articular joint while integrating with the underlying bone. The MSCs must achieve this goal to meet the functional tissue-engineering criteria defined by Butler et al. [73] for musculoskeletal repair. Thus, novel combinations of growth factors and scaffolds may provide the means to regulate the differentiation of MSCs for applications in the tissue-engineered repair or regeneration of articular cartilage. Similarly, other environmental factors such as the properties of the extracellular matrix [74], mechanical stimuli [75], or oxygen tension [76] can significantly influence the growth and chondrogenic differentiation of these cells. 


\section{Myogenesis}

The adipose- and bone marrow-derived MSCs display the capacity to express biochemical markers characteristic of cardiac, skeletal, and smooth muscle myocytes (table 2). Exposure of MSCs to 5-azacytidine led to the expression of cardiac myocytes markers, including atrial natriuretic peptide and the transcription factor GATA4, as well as the presence of electrophysiologically active, beating cells [77]. Similar results have been achieved by co-culturing MSCs with cardiomyocytes or by incorporating cardiomyocyte protein extracts into MSCs directly [78]. Exposure of the MSCs to low serum concentrations or horse serum led to the expression of skeletal myocyte markers such as the transcription factor myogenin and the presence of multi-nucleated myotubes. Finally, MSCs maintained in serum-containing medium alone displayed characteristic markers of smooth muscle cells, such as $\alpha$ smooth muscle actin, suggesting that in some cases spontaneous myogenic differentiation of MSCs is possible [79, 80]. In vivo, there are multiple mechanisms through which MSCs can promote myogenic repair. These include direct myogenic lineage differentiation, fusion to existing but damaged myocytes, release of paracrine cytokines/factors, and/or scavenging of reactive oxygen species. For excellent reviews covering the recent literature relating to the use of MSCs to treat myocardial infarction the reader is referred to $[81,82]$.

\section{Tendons and Ligaments}

Early reports in non-human models have documented the ability of bone marrow MSCs to display the cellular, nuclear morphological, and longitudinal alignment changes consistent with tenocytic differentiation [83-85]. Tendon properties could be improved by combining the MSCs with composite biomaterial scaffolds and mechanically loading the constructs in vitro using bioreactors. The addition of a collagen type I sponge helped to assimilate material stiffness to within the range of forces and tissue displacement experienced by patellar tendons in vivo [86]. While the MSC seeding density did not affect biomechanical properties significantly, it did lead to ectopic bone formation at cell preparations of $>1$ million cells/ml [87]; however, this undesired consequence could be reduced by lowering the cell-to-collagen ratio [88]. While few published reports have systematically explored the tenocytic differentiation of human MSCs from adipose or bone marrow origin, this area of research merits increased scrutiny. The recent isolation of multipotent stem cells from murine tendons may shed light on this subject [89].

\section{Ectodermal Lineage Potential}

\section{Central Nervous System}

Human, non-human primate, and murine MSCs display biochemical and morphological characteristics of neuronal-, and oligodendrocyte-like cells when cultured in the presence of antioxidants and the absence of serum [26, 90-94]. Similar induction has been obtained in response to indomethacin, insulin, and methylisobutylxanthine $[95,96]$. The MSCs express the neuronally associated markers nestin, NeuN, and intermediate filament. They also express the oligodendrocyte marker, glial fibrillary acidic protein (GFAP). Further studies with murine MSCs have detected the neuronally associated glutamate receptor subunits NR1 and NR2, MAP2, S-100, and $\beta$-III tubulin $[97,98]$. The differentiated murine MSCs exhibited reduced viability in the presence of $\mathrm{N}$-methyl D-aspartate (NMDA), consistent with a neuronal phenotype [94]. Rat MSCs have also been demonstrated to differentiate into olfactory ensheathing-like cells (OECs) when cultured on threedimensional collagen scaffold in the presence of terminally differentiated OECs [99]. To date, no studies have clearly demonstrated that MSCs exhibit the full functionality profile of mature neuronal or glial cells. This area of research merits further investigation since studies of bone marrow MSCs suggest that the expression of neuronal biochemical features alone is not sufficient evidence to document true differentiation [100, 101]. Our group (Bunnell et al., unpublished observations) and others $[100,101]$ have data that indicate that both adipose- and bone marrow-derived MSCs express nestin and other markers in response to cytoskeletal disruption and extreme stress.

The release of neurotrophic factors by MSCs may also mediate the therapeutic efficacy observed in CNS disease models. MSCs have been shown to express a variety of neurotrophic factors that can mediate neuronal cell survival, induce proliferation of endogenous cells, and promote the regeneration of nerve fibers, including brain-derived neurotrophic factor, ciliary neurotrophic factor, nerve growth factor, and vascular endothelial growth factor [102-108]. Human adipose-derived MSCs promoted the growth and differentiation of isolated murine neural stem cells in a cell contact-dependent manner while murine 3T3-L1 adipocytes supported neurite outgrowths through the release of angiopoietin 1 [109-111]. Thus, paracrine factors released by MSCs or stimulated by their presence may account for the beneficial effects of MSC transplants on central nervous system injury models. Interrogation of the human adipose-derived MSC transcriptome identified expressed mRNAs encoding various cytokines, neurite-inducing factors and neural cell adhesion molecules (Bunnell et al., unpublished observations). Similar to bone marrow-derived MSCs, it is evident that adipose-derived MSCs may express neurotrophins and other potent neuroregulatory molecules. Thus, paracrine factors released by MSCs or stimulated by their presence may account for the beneficial effects of adipose tissue-derived MSC transplants on central nervous system injury models. Taken together these data raise the possibility of therapeutic applications for neural and glial tissue repair using MSCs, even though they are derived from mesenchymal germ layer instead of the ectodermal germ layer. 
Table 4. In vitro epidermal and endodermal lineage differentiation potential: Highlights from the literature

\begin{tabular}{|c|c|c|c|}
\hline Lineage & Inductive factors & $\begin{array}{l}\text { Adipose-derived } \\
\text { MSCs }\end{array}$ & $\begin{array}{l}\text { Bone marrow- } \\
\text { derived MSCs }\end{array}$ \\
\hline Epithelial & all trans retinoic acid & {$[112]$} & {$[204]$} \\
\hline B-Islet & $\begin{array}{l}\text { nicotinamide, activin, extendin, } \\
\text { pentagastrin, hepatocyte growth factor }\end{array}$ & {$[117]$} & {$[118,119]$} \\
\hline Hepatocyte & $\begin{array}{l}\text { hepatocyte growth factor, oncostatin } \mathrm{M} \text {, } \\
\text { fibroblast growth factor } 2 \text {, nicotinamide }\end{array}$ & $\begin{array}{l}{[114,116,205]} \\
\text { non-human }[206]\end{array}$ & {$[113,207,208]$} \\
\hline Neuronal/glial & $\begin{array}{l}\text { antioxidants, indomethacin, insulin, } \\
\text { isobutylmethylxanthine }\end{array}$ & {$[92-95,128,209]$} & [210-212] \\
\hline
\end{tabular}

\section{Epithelial}

The number of studies exploring epithelial differentiation potential of MSCs is limited (table 4). Human adipose MSCs have been noted to undergo epithelial cell differentiation in the presence of all-trans retinoic acid in vitro [112]. The MSCs displayed morphological changes characteristic of epithelial cells and expressed the lineage-specific marker cytokeratin 18 [112]. This remains an area for further investigation.

\section{Endodermal Lineage Potential}

\section{Hepatic}

Both adipose- and bone marrow-derived MSCs display biochemical characteristics of hepatocytes when cultured in the presence of hepatocyte growth factor (HGF), oncostatin M, and DMSO or in the presence of HGF, bFGF, and nicotinamide (table 4); these included albumin, $\alpha$-fetoprotein, and urea production [113-115]. In a direct comparison, human adipose- and bone marrow-derived MSCs displayed similar hepatogenic differentiation in vitro [116]. It remains to be determined if MSCs can enhance hepatocyte differentiation through the delivery of paracrine factors or through some other mechanism.

\section{Pancreatic}

Adipose MSCs can display biochemical characteristics of pancreatic cells (table 4) [117]. In the absence of serum and the presence of nicotinamide and the growth factors activin, extendin, hepatocyte growth factor, and pentagastrin, MSCs expressed mRNAs for the pancreatic hormones glucagon, insulin, and somatostatin and the transcription factors isl-1, Ipf-1, Ngn-3, and Pax-6 [117]. Similar results have been achieved in bone marrow MSCs by genetic manipulation and/or co-culture with $\beta$-islet cells $[118,119]$. Following transfection with a construct expressing the $\beta$-islet-associated transcription factor pancreatic duodenal homeobox1 (pdx1), MSCs expressed insulin and related pancreatic peptides. Furthermore, the MSCs were sensitive to environmental glucose levels with respect to insulin release [119]. These preliminary studies relating to endodermal tissue offer promise for regenerative medical use of MSCs beyond the traditional mesenchymal pathways.

\section{Genetic Advances}

Recent advance in stem cell biology have provided encouragement in the ability to manipulate non-embryonic stem cells. Two groups recently reported that they have reprogrammed human skin cells into so-called induced pluripotent cells (iPCs) [120, 121]. Takahashi and Yamanaka [122] used a retrovirus to ferry into adult cells the same four genes they had previously employed to reprogram mouse cells: OCT3/4, $S O X 2, K L F 4$, and $c-M Y C$. They reprogrammed cells taken from the facial skin of a 36-year-old woman and from the connective tissue of a 69-year-old man. Roughly one iPC cell line was produced for every 5,000 cells they treated with the technique, an efficiency that enabled them to produce several cell lines from each experiment. Yu et al. [121] obtained similar results using the transcription factor combination of OCT4, SOX2, NANOG, and LIN28 [121]. These studies set an important precedent that potentially provides a path to manipulate pluripotent cells from non-embryonic origin, such as adiposeand bone marrow-derived MSCs, towards desired cell phenotypes (i.e. osteoblasts, chondrocytes, myoblasts) and at the same time preventing differentiation towards cells of undesired phenotype (i.e. adipocytes).

\section{Acknowledgements}

The authors wish to thank Ms. Laura Dallam for assistance with the manuscript preparation. This work was partially supported by a CNRU Center Grant \# 1P30 DK072476 entitled 'Nutritional Programming: Environmental and Molecular Interactions' sponsored by NIDDK (JMG), NIH grants AR50245 and AG15768 (FG), and the Pennington Biomedical Research Foundation. 


\section{References}

1 Friedenstein AJ: Precursor cells of mechanocytes. Int Rev Cytol 1976;47:327-359.

2 Friedenstein AJ, Chailakhjan RK, Lalykina KS: The development of fibroblast colonies in monolayer cultures of guinea-pig bone marrow and spleen cells. Cell Tissue Kinet 1970;3:393-403.

3 Owen M: Marrow stromal stem cells. J Cell Sci Suppl 1988;10:63-76.

4 Tavassoli M, Crosby WH: Bone marrow histogenesis: a comparison of fatty and red marrow. Science 1970;169:291-293

5 Friedenstein AJ, Lalykina KS: Thymus cells are inducible to osteogenesis. Eur J Immunol 1972;2: 602-603.

6 Gimble JM: The function of adipocytes in the bone marrow stroma. New Biol 1990;2:304-312.

7 Gimble JM, Robinson CE, Wu X, Kelly KA: The function of adipocytes in the bone marrow stroma: an update. Bone 1996;19:421-428.

8 Nuttall ME, Gimble JM: Controlling the balance between osteoblastogenesis and adipogenesis and the consequent therapeutic implications. Curr Opin Pharmacol 2004;4:290-294.

9 Gimble JM, Zvonic S, Floyd ZE, Kassem M, Nuttall ME: Playing with bone and fat. J Cell Biochem 2006;98:251-266.

10 Caplan AI: Mesenchymal stem cells. J Orthop Res 1991;9:641-650.

11 Caplan AI: Osteogenesis imperfecta, rehabilitation medicine, fundamental research and mesenchymal stem cells. Connect Tissue Res 1995;31:S9-14.

12 Caplan AI: The mesengenic process. Clin Plast Surg 1994;21:429-435.

13 Caplan AI: Review: mesenchymal stem cells: cellbased reconstructive therapy in orthopedics. Tissue Eng 2005;11:1198-1211.

14 English D: Preserve mesenchymal stem cell research. Stem Cells Dev 2007;16:1-2.

15 Dominici M, Le Blanc K, Mueller I, Slaper-Cortenbach I, Marini F, Krause D, Deans R, Keating A, Prockop D, Horwitz E: Minimal criteria for defining multipotent mesenchymal stromal cells. The International Society for Cellular Therapy position statement. Cytotherapy 2006;8:315-317.

16 Gronthos S, Franklin DM, Leddy HA, Robey PG, Storms RW, Gimble JM: Surface protein characterization of human adipose tissue-derived stromal cells. J Cell Physiol 2001;189:54-63.

17 Gronthos S, Zannettino AC, Hay SJ, Shi S, Graves SE, Kortesidis A, Simmons PJ: Molecular and cellular characterisation of highly purified stromal stem cells derived from human bone marrow. J Cell Sci 2003;116:1827-1835.

18 Haynesworth SE, Baber MA, Caplan AI: Cell surface antigens on human marrow-derived mesenchymal cells are detected by monoclonal antibodies. Bone 1992;13:69-80.

19 Bruder SP, Ricalton NS, Boynton RE, Connolly TJ, Jaiswal N, Zaia J, Barry FP: Mesenchymal stem cell surface antigen SB-10 corresponds to activated leukocyte cell adhesion molecule and is involved in osteogenic differentiation. J Bone Miner Res 1998; 13:655-663.

20 Bruder SP, Horowitz MC, Mosca JD, Haynesworth SE: Monoclonal antibodies reactive with human osteogenic cell surface antigens. Bone 1997;21:225235.

21 Simmons PJ, Torok-Storb B: Identification of stromal cell precursors in human bone marrow by a novel monoclonal antibody, STRO-1. Blood 1991; 78:55-62.
Kilroy GE, Foster S, Wu X, Ruiz J, Sherwood S, Heifetz A, Ludlow JW, Stricker DM, Potiny S, Green P, Halvorsen YDC, Cheatham B, Storms RW, Gimble JM: Cytokine profile of human adipose-derived stem cells: expression of angiogenic, hematopoietic, and pro-inflammatory factors. J Cell Physiol 2007;212:702-709.

23 Delany J, Floyd ZE, Zvonic S, Smith A, Gravois A, Reiners E, Wu X, Kilroy G, Lefevre M, Gimble JM: Proteomic analysis of primary cultures of human adipose derived stem cells: Modulation by adipogenesis. Mol Cell Proteomics 2005;4:731-740.

24 Zvonic S, Lefevre M, Kilroy G, Floyd ZE, Delany JP, Kheterpal I, Gravois A, Dow R, White A, Wu X, Gimble JM: Secretome of primary cultures of human adipose-derived stem cells (ASCs): modulation of serpins by adipogenesis. Mol Cell Proteomics 2007;6:18-28.

25 Mitchell JB, McIntosh K, Zvonic S, Garrett S, Floyd ZE, Kloster A, Di Halvorsen Y, Storms RW, Goh B, Kilroy G, Wu X, Gimble JM: The immunophenotype of human adipose derived cells: Temporal changes in stromal- and stem cell-associated markers Stem Cells 2006;24:376-385.

26 Zuk PA, Zhu M, Ashjian P, De Ugarte DA, Huang JI, Mizuno H, Alfonso ZC, Fraser JK, Benhaim P, Hedrick MH: Human adipose tissue is a source of multipotent stem cells. Mol Biol Cell 2002;13: 4279-4295.

27 Katz AJ, Tholpady A, Tholpady SS, Shang H, Ogle RC: Cell surface and transcriptional characterization of human adipose-derived adherent stromal (hADAS) Cells. Stem Cells 2005;23:412-423.

28 Horwitz EM, Le Blanc K, Dominici M, Mueller I, Slaper-Cortenbach I, Marini FC, Deans RJ, Krause DS, Keating A: Clarification of the nomenclature for MSC: the International Society for Cellular Therapy position statement. Cytotherapy 2005;7: 393-395.

29 D'Ippolito G, Schiller PC, Ricordi C, Roos BA, Howard GA: Age-related osteogenic potential of mesenchymal stromal stem cells from human vertebral bone marrow. J Bone Miner Res 1999;14: 1115-1122.

30 Lei L, Liao W, Sheng P, Fu M, He A, Huang G: Biological character of human adipose-derived adult stem cells and influence of donor age on cell replication in culture. Sci China C Life Sci 2007;50: 320-328.

31 Arai F, Hirao A, Suda T: Regulation of hematopoiesis and its interaction with stem cell niches. Int J Hematol 2005;82:371-376.

32 Calvi LM, Adams GB, Weibrecht KW, Weber JM, Olson DP, Knight MC, Martin RP, Schipani E, Divieti P, Bringhurst FR, Milner LA, Kronenberg HM, Scadden DT: Osteoblastic cells regulate the haematopoietic stem cell niche. Nature 2003;425: 841-846. 33 Kincade PW, Lee G, Pietrangeli CE, Hayashi S, Gimble JM: Cells and molecules that regulate B lymphopoiesis in bone marrow. Annu Rev Immunol 1989;7:111-143.

34 Taichman RS, Emerson SG: Human osteoblasts support hematopoiesis through the production of granulocyte colony-stimulating factor. J Exp Med 1994;179:1677-1682.

35 Yin T, Li L: The stem cell niches in bone. J Clin Invest 2006;116:1195-1201.

36 Corre J, Barreau C, Cousin B, Chavoin JP, Caton D, Fournial G, Penicaud L, Casteilla L, Laharrague P: Human subcutaneous adipose cells support complete differentiation but not self-renewal of hematopoietic progenitors. J Cell Physiol 2006;208: 282-288.
7 Miyake K, Underhill CB, Lesley J, Kincade PW: Hyaluronate can function as a cell adhesion molecule and CD44 participates in hyaluronate recognition. J Exp Med 1990;172:69-75.

38 Oritani K, Wu X, Medina K, Hudson J, Miyake K, Gimble JM, Burstein SA, Kincade PW: Antibody ligation of $\mathrm{CD} 9$ modifies production of myeloid cells in long-term cultures. Blood 1996;87:22522261.

39 Jacobsen K, Miyake K, Kincade PW, Osmond DG: Highly restricted expression of a stromal cell determinant in mouse bone marrow in vivo. J Exp Med 1992;176:927-935.

40 Jacobsen K, Kravitz J, Kincade PW, Osmond DG: Adhesion receptors on bone marrow stromal cells: in vivo expression of vascular cell adhesion molecule- 1 by reticular cells and sinusoidal endothelium in normal and gamma-irradiated mice. Blood 1996; 87:73-82.

41 Gimble JM, Pietrangeli C, Henley A, Dorheim MA, Silver J, Namen A, Takeichi M, Goridis C, Kincade PW: Characterization of murine bone marrow and spleen-derived stromal cells: analysis of leukocyte marker and growth factor mRNA transcript levels. Blood 1989;74:303-311.

42 Lee MJ, Song HY, Kim MR, Sung SM, Jung JS, Kim JH: Oncostatin M stimulates expression of stromalderived factor-1 in human mesenchymal stem cells. Int J Biochem Cell Biol 2007;39:650-659.

43 Pittenger MF, Mackay AM, Beck SC, Jaiswal RK Douglas R, Mosca JD, Moorman MA, Simonetti DW, Craig S, Marshak DR: Multilineage potential of adult human mesenchymal stem cells. Science 1999;284:143-147.

44 Aust L, Devlin B, Foster SJ, Halvorsen YD, Hicok K, du Laney T, Sen A, Willingmyre GD, Gimble JM: Yield of human adipose-derived adult stem cells from liposuction aspirates. Cytotherapy 2004; 6:7-14.

45 Wickham MQ, Erickson GR, Gimble JM, Vail TP, Guilak F: Multipotent stromal cells derived from the infrapatellar fat pad of the knee. Clin Orthop 2003:196-212.

46 Majumdar MK, Thiede MA, Haynesworth SE, Bruder SP, Gerson SL: Human marrow-derived mesenchymal stem cells (MSCs) express hematopoietic cytokines and support long-term hematopoiesis when differentiated toward stromal and osteogenic lineages. J Hematother Stem Cell Res 2000;9:841-848.

47 Majumdar MK, Thiede MA, Mosca JD, Moorman M, Gerson SL: Phenotypic and functional comparison of cultures of marrow-derived mesenchymal stem cells (MSCs) and stromal cells. J Cell Physiol 1998;176:57-66.

48 Sensebe L, Deschaseaux M, Li J, Herve P, Charbord $\mathrm{P}$ : The broad spectrum of cytokine gene expression by myoid cells from the human marrow microenvironment. Stem Cells 1997;15:133-143.

49 Bartholomew A, Sturgeon C, Siatskas M, Ferrer K, McIntosh K, Patil S, Hardy W, Devine S, Ucker D, Deans R, Moseley A, Hoffman R: Mesenchymal stem cells suppress lymphocyte proliferation in vitro and prolong skin graft survival in vivo. Exp Hematol 2002;30:42-48.

50 Le Blanc K, Tammik L, Sundberg B, Haynesworth SE, Ringden O: Mesenchymal stem cells inhibit and stimulate mixed lymphocyte cultures and mitogenic responses independently of the major histocompatibility complex. Scand J Immunol 2003;57:11-20. 
-51 Puissant B, Barreau C, Bourin P, Clavel C, Corre J, Bousquet C, Taureau C, Cousin B, Abbal M, Laharrague $\mathrm{P}$, Penicaud L, Casteilla L, Blancher A: Immunomodulatory effect of human adipose tissuederived adult stem cells: comparison with bone marrow mesenchymal stem cells. Br J Haematol 2005;129:118-129.

52 McIntosh K, Zvonic S, Garrett S, Mitchell JB, Floyd ZE, Hammill L, Kloster A, Halvorsen YD, Ting JP, Storms RW, Goh B, Kilroy G, Wu X, Gimble JM: The immunogenicity of human adipose derived cells: Temporal changes in vitro. Stem Cells 2006;24: 1245-1253.

53 Le Blanc K, Rasmusson I, Sundberg B, Gotherstrom C, Hassan M, Uzunel M, Ringden O: Treatment of severe acute graft-versus-host disease with third party haploidentical mesenchymal stem cells. Lancet 2004;363:1439-1441.

54 Le Blanc K, Ringden O: Immunomodulation by mesenchymal stem cells and clinical experience. J Intern Med 2007;262:509-525.

55 Schwartz AV, Sellmeyer DE, Vittinghoff E, Palermo L, Lecka-Czernik B, Feingold KR, Strotmeyer ES, Resnick HE, Carbone L, Beamer BA, Won Park S, Lane NE, Harris TB, Cummings SR: Thiazolidinedione (TZD) use and bone loss in older diabetic adults. J Clin Endocrinol Metab 2006;91: 3349-3354.

56 Diascro DD Jr, Vogel RL, Johnson TE, Witherup KM, Pitzenberger SM, Rutledge SJ, Prescott DJ, Rodan GA, Schmidt A: High fatty acid content in rabbit serum is responsible for the differentiation of osteoblasts into adipocyte-like cells. J Bone Miner Res 1998;13:96-106.

57 Gimble JM, Dorheim MA, Cheng Q, Medina K, Wang CS, Jones R, Koren E, Pietrangeli C, Kincade PW: Adipogenesis in a murine bone marrow stromal cell line capable of supporting B lineage lymphocyte growth and proliferation: biochemical and molecular characterization. Eur J Immunol 1990;20: 379-387.

58 Halvorsen YD, Bond A, Sen A, Franklin DM, LeaCurrie YR, Sujkowski D, Ellis PN, Wilkison WO, Gimble JM: Thiazolidinediones and glucocorticoids synergistically induce differentiation of human adipose tissue stromal cells: biochemical, cellular, and molecular analysis. Metabolism 2001;50:407-413.

-59 Sen A, Lea-Currie YR, Sujkowska D, Franklin DM, Wilkison WO, Halvorsen YD, Gimble JM: Adipogenic potential of human adipose derived stromal cells from multiple donors is heterogeneous. J Cell Biochem 2001;81:312-319.

60 Beresford JN, Bennett JH, Devlin C, Leboy PS, Owen ME: Evidence for an inverse relationship between the differentiation of adipocytic and osteogenic cells in rat marrow stromal cell cultures. J Cell Sci 1992;102:341-351.

61 Dorheim MA, Sullivan M, Dandapani V, Wu X, Hudson J, Segarini PR, Rosen DM, Aulthouse AL, Gimble JM: Osteoblastic gene expression during adipogenesis in hematopoietic supporting murine bone marrow stromal cells. J Cell Physiol 1993;154: 317-328.

62 Gimble JM, Nuttall ME: Bone and fat: old questions, new insights. Endocrine 2004;23:183-188.

63 Floyd ZE, Zvonic S, Nuttall ME, Gimble JM: Finetuning reception in the bone: PPARgamma and company. PPAR Res 2006;2006:52950.

64 Lecka-Czernik B, Gubrij I, Moerman EJ, Kajkenova O, Lipschitz DA, Manolagas SC, Jilka RL: Inhibition of Osf2/Cbfa1 expression and terminal osteoblast differentiation by PPARgamma2. J Cell Biochem 1999;74:357-371.
65 Lecka-Czernik B, Moerman EJ, Grant DF, Lehmann JM, Manolagas SC, Jilka RL: Divergent effects of selective peroxisome proliferator-activated receptor-gamma 2 ligands on adipocyte versus osteoblast differentiation. Endocrinology 2002;143: 2376-2384.

66 Duque G, Rivas D: Alendronate has an anabolic effect on bone through the differentiation of mesenchymal stem cells. J Bone Miner Res 2007;22: 1603-1611.

67 Chen D, Ji X, Harris MA, Feng JQ, Karsenty G, Celeste AJ, Rosen V, Mundy GR, Harris SE: Differential roles for bone morphogenetic protein (BMP) receptor type IB and IA in differentiation and specification of mesenchymal precursor cells to osteoblast and adipocyte lineages. J Cell Biol 1998; 142:295-305.

68 Bowers RR, Kim JW, Otto TC, Lane MD: Stable stem cell commitment to the adipocyte lineage by inhibition of DNA methylation: role of the BMP-4 gene. Proc Natl Acad Sci U S A 2006;103: 13022-13027.

69 Bowers RR, Lane MD: A role for bone morphogenetic protein-4 in adipocyte development. Cell Cycle 2007;6:385-389.

70 Estes BT, Wu AW, Guilak F: Potent induction of chondrocytic differentiation of human adipose-derived adult stem cells by bone morphogenetic protein 6. Arthritis Rheum 2006;54:1222-1232.

71 Sekiya I, Colter DC, Prockop DJ: BMP-6 enhances chondrogenesis in a subpopulation of human marrow stromal cells. Biochem Biophys Res Commun 2001;284:411-418.

72 Shao XX, Hutmacher DW, Ho ST, Goh JC, Lee EH: Evaluation of a hybrid scaffold/cell construct in repair of high-load-bearing osteochondral defects in rabbits. Biomaterials 2006;27:1071-1080.

73 Butler DL, Goldstein SA, Guilak F: Functional tissue engineering: the role of biomechanics. J Biomech Eng 2000;122:570-575.

74 Betre H, Ong SR, Guilak F, Chilkoti A, Fermor B, Setton LA: Chondrocytic differentiation of human adipose-derived adult stem cells in elastin-like polypeptide. Biomaterials 2006;27:91-99.

75 Estes BT, Gimble JM, Guilak F: Mechanical signals as regulators of stem cell fate. Curr Top Dev Biol 2004;60:91-126.

76 Wang DW, Fermor B, Gimble JM, Awad HA, Guilak F: Influence of oxygen on the proliferation and metabolism of adipose derived adult stem cells. J Cell Physiol 2005;204:184-191.

77 Planat-Benard V, Menard C, Andre M, Puceat M, Perez A, Garcia-Verdugo JM, Penicaud L, Casteilla L: Spontaneous cardiomyocyte differentiation from adipose tissue stroma cells. Circ Res 2004;94: 223-229.

78 Gaustad KG, Boquest AC, Anderson BE, Gerdes AM, Collas P: Differentiation of human adipose tissue stem cells using extracts of rat cardiomyocytes. Biochem Biophys Res Commun 2004;314:420-427.

79 Lee WC, Maul TM, Vorp DA, Rubin JP, Marra KG: Effects of uniaxial cyclic strain on adipose-derived stem cell morphology, proliferation, and differentiation. Biomech Model Mechanobiol 2007;6:265-273.

80 Lee WC, Rubin JP, Marra KG: Regulation of alphasmooth muscle actin protein expression in adiposederived stem cells. Cells Tissues Organs 2006;183: 80-86.

81 Pittenger MF, Martin BJ: Mesenchymal stem cells and their potential as cardiac therapeutics. Circ Res 2004;95:9-20.

82 Le Blanc K, Pittenger M: Mesenchymal stem cells: progress toward promise. Cytotherapy 2005;7:3645.
83 Huang D, Chang TR, Aggarwal A, Lee RC, Ehrlich HP: Mechanisms and dynamics of mechanical strengthening in ligament-equivalent fibroblastpopulated collagen matrices. Ann Biomed Eng 1993;21:289-305.

84 Young RG, Butler DL, Weber W, Caplan AI, Gordon SL, Fink DJ: Use of mesenchymal stem cells in a collagen matrix for Achilles tendon repair. J Orthop Res 1998;16:406-413.

85 Awad HA, Butler DL, Harris MT, Ibrahim RE, Wu Y, Young RG, Kadiyala S, Boivin GP: In vitro characterization of mesenchymal stem cell-seeded collagen scaffolds for tendon repair: effects of initial seeding density on contraction kinetics. J Biomed Mater Res 2000;51:233-240.

86 Juncosa-Melvin N, Boivin GP, Gooch C, Galloway MT, West JR, Dunn MG, Butler DL: The effect of autologous mesenchymal stem cells on the biomechanics and histology of gel-collagen sponge constructs used for rabbit patellar tendon repair. Tissue Eng 2006;12:369-379.

87 Awad HA, Boivin GP, Dressler MR, Smith FN Young RG, Butler DL: Repair of patellar tendon injuries using a cell-collagen composite. J Orthop Res 2003;21:420-431.

88 Juncosa-Melvin N, Boivin GP, Galloway MT, Gooch C, West JR, Sklenka AM, Butler DL: Ef fects of cell-to-collagen ratio in mesenchymal stem cell-seeded implants on tendon repair biomechanics and histology. Tissue Eng 2005;11:448-457.

89 Bi Y, Ehirchiou D, Kilts TM, Inkson CA, Embree MC, Sonoyama W, Li L, Leet AI, Seo BM, Zhang L, Shi S, Young MF: Identification of tendon stem/ progenitor cells and the role of the extracellular matrix in their niche. Nat Med 2007;13: 1219-1227.

90 Kang SK, Putnam LA, Ylostalo J, Popescu IR, Dufour J, Belousov A, Bunnell BA: Neurogenesis of Rhesus adipose stromal cells. J Cell Sci 2004;117: 4289-4299.

91 Krampera M, Marconi S, Pasini A, Galie M, Rigotti G, Mosna F, Tinelli M, Lovato L, Anghileri E, Andreini A, Pizzolo G, Sbarbati A, Bonetti B: Induction of neural-like differentiation in human mesenchymal stem cells derived from bone marrow, fat, spleen and thymus. Bone 2007;40:382-390.

92 Safford KM, Hicok KC, Safford SD, Halvorsen YD, Wilkison WO, Gimble JM, Rice HE: Neurogenic differentiation of murine and human adipose-derived stromal cells. Biochem Biophys Res Commun 2002;294:371-379.

93 Safford KM, Rice HE: Stem cell therapy for neurologic disorders: therapeutic potential of adipose-derived stem cells. Curr Drug Targets 2005;6:57-62.

94 Safford KM, Safford SD, Gimble JM, Shetty AK, Rice HE: Characterization of neuronal/glial differentiation of murine adipose-derived adult stromal cells. Exp Neurol 2004;187:319-328.

95 Ashjian PH, Elbarbary AS, Edmonds B, DeUgarte D, Zhu M, Zuk PA, Lorenz HP, Benhaim P, Hedrick MH: In vitro differentiation of human processed lipoaspirate cells into early neural progenitors. Plast Reconstr Surg 2003;111:1922-1931.

96 Fujimura J, Ogawa R, Mizuno H, Fukunaga Y, Suzuki H: Neural differentiation of adipose-derived stem cells isolated from GFP transgenic mice. Biochem Biophys Res Commun 2005;333:116-121.

97 Sakaguchi Y, Sekiya I, Yagishita K, Muneta T: Comparison of human stem cells derived from various mesenchymal tissues: superiority of synovium as a cell source. Arthritis Rheum 2005:52:2521-2529. 
98 Yoshimura H, Muneta T, Nimura A, Yokoyama A, Koga H, Sekiya I: Comparison of rat mesenchyma stem cells derived from bone marrow, synovium, periosteum, adipose tissue, and muscle. Cell Tissue Res 2007;327:449-462.

99 Wang B, Han J, Gao Y, Xiao Z, Chen B, Wang X, Zhao W, Dai J: The differentiation of rat adiposederived stem cells into OEC-like cells on collagen scaffolds by co-culturing with OECs. Neurosci Lett 2007:421:191-196.

100 Lu P, Blesch A, Tuszynski MH: Induction of bone marrow stromal cells to neurons: differentiation, transdifferentiation, or artifact? J Neurosci Res 2004;77:174-191.

101 Neuhuber B, Gallo G, Howard L, Kostura L, Mackay A, Fischer I: Reevaluation of in vitro differentiation protocols for bone marrow stromal cells: disruption of actin cytoskeleton induces rapid morphological changes and mimics neuronal phenotype. J Neurosci Res 2004;77:192-204.

102 Chen KC, Minor TX, Rahman NU, Ho HC, Nunes L, Lue TF: The additive erectile recovery effect of brain-derived neurotrophic factor combined with vascular endothelial growth factor in a rat model of neurogenic impotence. BJU Int 2005;95: 1077-1080.

103 Chen X, Katakowski M, Li Y, Lu D, Wang L, Zhang L, Chen J, Xu Y, Gautam S, Mahmood A, Chopp M: Human bone marrow stromal cell cultures conditioned by traumatic brain tissue extracts: growth factor production. J Neurosci Res 2002;69:687-691.

104 Crigler L, Robey RC, Asawachaicharn A, Gaupp D, Phinney DG: Human mesenchymal stem cell subpopulations express a variety of neuro-regulatory molecules and promote neuronal cell survival and neuritogenesis. Exp Neurol 2006;198:54-64.

105 Mahmood A, Lu D, Chopp M: Marrow stroma cell transplantation after traumatic brain injury promotes cellular proliferation within the brain. Neurosurgery 2004;55:1185-1193.

106 Mahmood A, Lu D, Chopp M: Intravenous administration of marrow stromal cells (MSCs) increases the expression of growth factors in rat brain after traumatic brain injury. J Neurotrauma 2004;21 33-39.

107 Mahmood A, Lu D, Qu C, Goussev A, Chopp M Human marrow stromal cell treatment provides long-lasting benefit after traumatic brain injury in rats. Neurosurgery 2005;57:1026-1031;discussion 1026-1031.

108 Munoz JR, Stoutenger BR, Robinson AP, Spees JL, Prockop DJ: Human stem/progenitor cells from bone marrow promote neurogenesis of endogenous neural stem cells in the hippocampus of mice. Proc Natl Acad Sci U S A 2005;102: 18171-18176.

109 Kang SK, Jun ES, Bae YC, Jung JS: Interactions between human adipose stromal cells and mouse neural stem cells in vitro. Brain Res Dev Brain Res 2003;145:141-149.

110 Kosacka J, Figiel M, Engele J, Hilbig H, Majewski M, Spanel-Borowski K: Angiopoietin-1 promotes neurite outgrowth from dorsal root ganglion cells positive for Tie-2 receptor. Cell Tissue Res 2005; 320:11-19.

111 Kosacka J, Nowicki M, Kacza J, Borlak J, Engele J, Spanel-Borowski K: Adipocyte-derived angiopoietin-1 supports neurite outgrowth and synaptogenesis of sensory neurons. J Neurosci Res 2006;83: 1160-1169.
112 Brzoska M, Geiger H, Gauer S, Baer P: Epithelial differentiation of human adipose tissue-derived adult stem cells. Biochem Biophys Res Commun 2005;330:142-150.

113 Lee KD, Kuo TK, Whang-Peng J, Chung YF, Lin CT, Chou SH, Chen JR, Chen YP, Lee OK: In vitro hepatic differentiation of human mesenchymal stem cells. Hepatology 2004;40:1275-1284.

114 Seo MJ, Suh SY, Bae YC, Jung JS: Differentiation of human adipose stromal cells into hepatic lineage in vitro and in vivo. Biochem Biophys Res Commun 2005;328:258-264.

115 Talens-Visconti R, Bonora A, Jover R, Mirabet V, Carbonell F, Castell JV, Gomez-Lechon MJ: Human mesenchymal stem cells from adipose tissue: differentiation into hepatic lineage. Toxicol In Vitro 2007;21:324-329.

116 Talens-Visconti R, Bonora A, Jover R, Mirabet V, Carbonell F, Castell JV, Gomez-Lechon MJ: Hepatogenic differentiation of human mesenchymal stem cells from adipose tissue in comparison with bone marrow mesenchymal stem cells. World J Gastroenterol 2006;12:5834-5845.

117 Timper K, Seboek D, Eberhardt M, Linscheid P, Christ-Crain M, Keller U, Muller B, Zulewski H: Human adipose tissue-derived mesenchymal stem cells differentiate into insulin, somatostatin, and glucagon expressing cells. Biochem Biophys Res Commun 2006;341:1135-1140.

118 Moriscot C, de Fraipont F, Richard MJ, Marchand M, Savatier P, Bosco D, Favrot M, Benhamou PY: Human bone marrow mesenchymal stem cells can express insulin and key transcription factors of the endocrine pancreas developmental pathway upon genetic and/or microenvironmental manipulation in vitro. Stem Cells 2005;23:594-603.

119 Karnieli O, Izhar-Prato Y, Bulvik S, Efrat S: Generation of insulin-producing cells from human bone marrow mesenchymal stem cells by genetic manipulation. Stem Cells 2007;25:2837-2844.

120 Takahashi K, Tanabe K, Ohnuki M, Narita M, Ichisaka T, Tomoda K, Yamanaka S: Induction of pluripotent stem cells from adult human fibroblasts by defined factors. Cell 2007;131:861-872.

121 Yu J, Vodyanik MA, Smuga-Otto K, AntosiewiczBourget J, Frane JL, Tian S, Nie J, Jonsdottir GA, Ruotti V, Stewart R, Slukvin, II, Thomson JA: Induced pluripotent stem cell lines derived from human somatic cells. Science 2007;318:1917-1920.

122 Takahashi K, Yamanaka S: Induction of pluripotent stem cells from mouse embryonic and adult fibroblast cultures by defined factors. Cell 2006; 126:663-676.

123 Zuk PA, Zhu M, Mizuno H, Huang J, Futrell JW, Katz AJ, Benhaim P, Lorenz HP, Hedrick MH: Multilineage cells from human adipose tissue: implications for cell-based therapies. Tissue Eng 2001;7:211-228.

124 Halvorsen YC, Wilkison WO, Gimble JM: Adipose-derived stromal cells - their utility and potential in bone formation. Int J Obes Relat Metab Disord 2000;24(suppl 4):S41-44.

125 Erickson GR, Gimble JM, Franklin DM, Rice HE, Awad H, Guilak F: Chondrogenic potential of adipose tissue-derived stromal cells in vitro and in vivo. Biochem Biophys Res Commun 2002;290: 763-769.

126 Halvorsen YD, Franklin D, Bond AL, Hitt DC, Auchter C, Boskey AL, Paschalis EP, Wilkison WO, Gimble JM: Extracellular matrix mineralization and osteoblast gene expression by human adipose tissue-derived stromal cells. Tissue Eng 2001; 7:729-741.
127 Rodriguez AM, Pisani D, Dechesne CA, TurcCarel C, Kurzenne JY, Wdziekonski B, Villageois A, Bagnis C, Breittmayer JP, Groux H, Ailhaud G, Dani C: Transplantation of a multipotent cell population from human adipose tissue induces dystrophin expression in the immunocompetent $\mathrm{mdx}$ mouse. J Exp Med 2005;201:1397-1405.

128 Guilak F, Lott KE, Awad HA, Cao Q, Hicok KC, Fermor B, Gimble JM: Clonal analysis of the differentiation potential of human adipose-derived adult stem cells. J Cell Physiol 2006;206:229-237.

129 Young HE, Mancini ML, Wright RP, Smith JC, Black AC Jr, Reagan CR, Lucas PA: Mesenchymal stem cells reside within the connective tissues of many organs. Dev Dyn 1995;202:137-144.

130 Dennis JE, Haynesworth SE, Young RG, Caplan AI: Osteogenesis in marrow-derived mesenchymal cell porous ceramic composites transplanted subcutaneously: effect of fibronectin and laminin on cell retention and rate of osteogenic expression. Cell Transplant 1992;1:23-32.

131 Haynesworth SE, Goshima J, Goldberg VM Caplan AI: Characterization of cells with osteogenic potential from human marrow. Bone 1992; 13: 81-88.

132 Kuznetsov SA, Krebsbach PH, Satomura K, Kerr J, Riminucci M, Benayahu D, Robey PG: Singlecolony derived strains of human marrow stromal fibroblasts form bone after transplantation in vivo J Bone Miner Res 1997;12:1335-1347.

133 Ashton BA, Allen TD, Howlett CR, Eaglesom CC Hattori A, Owen M: Formation of bone and cartilage by marrow stromal cells in diffusion chambers in vivo. Clin Orthop Relat Res 1980:294-307.

134 Owen ME, Cave J, Joyner CJ: Clonal analysis in vitro of osteogenic differentiation of marrow CFU-F. J Cell Sci 1987;87:731-738.

135 Whitlock CA, Tidmarsh GF, Muller-Sieburg C, Weissman IL: Bone marrow stromal cell lines with lymphopoietic activity express high levels of a pre-B neoplasia-associated molecule. Cell 1987;48: 1009-1021.

136 Hunt P, Robertson D, Weiss D, Rennick D, Lee F Witte ON: A single bone marrow-derived stromal cell type supports the in vitro growth of early lymphoid and myeloid cells. Cell 1987;48:997-1007.

137 Pietrangeli CE, Hayashi S, Kincade PW: Stromal cell lines which support lymphocyte growth: characterization, sensitivity to radiation and responsiveness to growth factors. Eur J Immunol 1988;18: 863-872.

138 Alsalameh S, Amin R, Gemba T, Lotz M: Identification of mesenchymal progenitor cells in normal and osteoarthritic human articular cartilage. Arthritis Rheum 2004;50:1522-1532.

139 Hiraoka K, Grogan S, Olee T, Lotz M: Mesenchymal progenitor cells in adult human articular cartilage. Biorheology 2006;43:447-454.

140 Silbermann M, Reddi AH, Hand AR, Leapman R von der Mark K, Franzen A: Chondroid bone arises from mesenchymal stem cells in organ culture of mandibular condyles. J Craniofac Genet Dev Biol 1987;7:59-79.

141 Dowthwaite GP, Bishop JC, Redman SN, Khan IM, Rooney P, Evans DJ, Haughton L, Bayram Z, Boyer S, Thomson B, Wolfe MS, Archer CW: The surface of articular cartilage contains a progenitor cell population. J Cell Sci 2004;117:889-897.

142 Gronthos S, Brahim J, Li W, Fisher LW, Cherman N, Boyde A, DenBesten P, Robey PG, Shi S: Stem cell properties of human dental pulp stem cells. J Dent Res 2002;81:531-535. 
143 Gronthos S, Mankani M, Brahim J, Robey PG, Shi S: Postnatal human dental pulp stem cells (DPSCs) in vitro and in vivo. Proc Natl Acad Sci U S A 2000;97:13625-13630.

144 Shi S, Robey PG, Gronthos S: Comparison of human dental pulp and bone marrow stromal stem cells by cDNA microarray analysis. Bone 2001;29: 532-539.

145 Miura M, Gronthos S, Zhao M, Lu B, Fisher LW, Robey PG, Shi S: SHED: stem cells from human exfoliated deciduous teeth. Proc Natl Acad Sci U S A 2003;100:5807-5812.

146 O'Driscoll SW, Fitzsimmons JS: The role of periosteum in cartilage repair. Clin Orthop Relat Res 2001:S190-207.

147 Gawronska-Kozak B: Regeneration in the ears of immunodeficient mice: identification and lineage analysis of mesenchymal stem cells. Tissue Eng 2004;10:1251-1265.

-148 Togo T, Utani A, Naitoh M, Ohta M, Tsuji Y, Morikawa N, Nakamura M, Suzuki S: Identification of cartilage progenitor cells in the adult ear perichondrium: utilization for cartilage reconstruction. Lab Invest 2006;86:445-457.

149 Lee JY, Qu-Petersen Z, Cao B, Kimura S, Jankowski R, Cummins J, Usas A, Gates C, Robbins P, Wernig A, Huard J: Clonal isolation of muscle-derived cells capable of enhancing muscle regeneration and bone healing. J Cell Biol 2000;150: 1085-1100.

150 Seale P, Asakura A, Rudnicki MA: The potential of muscle stem cells. Dev Cell 2001;1:333-342.

151 Jankowski RJ, Deasy BM, Huard J: Muscle-derived stem cells. Gene Ther 2002;9:642-647.

152 Zheng B, Cao B, Li G, Huard J: Mouse adiposederived stem cells undergo multilineage differentiation in vitro but primarily osteogenic and chondrogenic differentiation in vivo. Tissue Eng 2006; 12:1891-1901.

153 Barry FP, Murphy JM: Mesenchymal stem cells: clinical applications and biological characterization. Int J Biochem Cell Biol 2004;36:568-584.

154 Fickert S, Fiedler J, Brenner RE: Identification, quantification and isolation of mesenchymal progenitor cells from osteoarthritic synovium by fluorescence automated cell sorting. Osteoarthritis Cartilage 2003;11:790-800.

155 de Mos M, Koevoet WJ, Jahr H, Verstegen MM, Heijboer MP, Kops N, van Leeuwen JP, Weinans $\mathrm{H}$, Verhaar JA, van Osch GJ: Intrinsic differentiation potential of adolescent human tendon tissue: an in-vitro cell differentiation study. BMC Musculoskelet Disord 2007:8:16.

156 Salingcarnboriboon R, Yoshitake H, Tsuji K, Obinata M, Amagasa T, Nifuji A, Noda M: Establishment of tendon-derived cell lines exhibiting pluripotent mesenchymal stem cell-like property. Exp Cell Res 2003;287:289-300.

157 Gimble JM, Robinson CE, Wu X, Kelly KA, Rodriguez BR, Kliewer SA, Lehmann JM, Morris DC: Peroxisome proliferator-activated receptorgamma activation by thiazolidinediones induces adipogenesis in bone marrow stromal cells. Mo Pharmacol 1996;50:1087-1094.

158 Conget PA, Minguell JJ: Phenotypical and functional properties of human bone marrow mesenchymal progenitor cells. J Cell Physiol 1999;181: $67-73$

159 Hennig T, Lorenz H, Thiel A, Goetzke K, Dickhut A, Geiger F, Richter W: Reduced chondrogenic potential of adipose tissue derived stromal cells correlates with an altered TGFbeta receptor and BMP profile and is overcome by BMP-6. J Cell Physiol 2007;211:682-691.
160 Awad HA, Halvorsen YD, Gimble JM, Guilak F: Effects of transforming growth factor beta1 and dexamethasone on the growth and chondrogenic differentiation of adipose-derived stromal cells. Tissue Eng 2003;9:1301-1312.

161 Huang JI, Zuk PA, Jones NF, Zhu M, Lorenz HP, Hedrick MH, Benhaim P: Chondrogenic potential of multipotential cells from human adipose tissue. Plast Reconstr Surg 2004;113:585-594.

162 Huang JI, Kazmi N, Durbhakula MM, Hering TM, Yoo JU, Johnstone B: Chondrogenic potential of progenitor cells derived from human bone marrow and adipose tissue: a patient-matched comparison. J Orthop Res 2005;23:1383-1389.

163 Mackay AM, Beck SC, Murphy JM, Barry FP, Chichester CO, Pittenger MF: Chondrogenic differentiation of cultured human mesenchymal stem cells from marrow. Tissue Eng 1998;4:415-428.

164 Johnstone B, Hering TM, Caplan AI, Goldberg VM, Yoo JU: In vitro chondrogenesis of bone marrow-derived mesenchymal progenitor cells. Exp Cell Res 1998;238:265-272.

165 Miranville A, Heeschen C, Sengenes C, Curat CA, Busse R, Bouloumie A: Improvement of postnatal neovascularization by human adipose tissue-derived stem cells. Circulation 2004:110:349-355.

166 Planat-Benard V, Silvestre JS, Cousin B, Andre M, Nibbelink M, Tamarat R, Clergue M, Manneville C, Saillan-Barreau C, Duriez M, Tedgui A, Levy B, Penicaud L, Casteilla L: Plasticity of human adipose lineage cells toward endothelial cells: physiological and therapeutic perspectives. Circulation 2004;109:656-663.

167 Rehman J, Traktuev D, Li J, Merfeld-Clauss S, Temm-Grove CJ, Bovenkerk JE, Pell CL, Johnstone BH, Considine RV, March KL: Secretion of angiogenic and antiapoptotic factors by human adipose stromal cells. Circulation 2004;109:12921298.

168 Nakagami H, Maeda K, Morishita R, Iguchi S, Nishikawa T, Takami Y, Kikuchi Y, Saito Y, Tamai K, Ogihara T, Kaneda Y: Novel autologous cell therapy in ischemic limb disease through growth factor secretion by cultured adipose tissue-derived stromal cells. Arterioscler Thromb Vasc Biol 2005; 25:2542-2547.

169 Pelletier L, Regnard J, Fellmann D, Charbord P: An in vitro model for the study of human bone marrow angiogenesis: role of hematopoietic cytokines. Lab Invest 2000;80:501-511.

170 Corre J, Planat-Benard V, Corberand JX, Penicaud L, Casteilla L, Laharrague P: Human bone marrow adipocytes support complete myeloid and lymphoid differentiation from human CD34 cells. Br J Haematol 2004:127:344-347.

171 Dittel BN, McCarthy JB, Wayner EA, LeBien TW: Regulation of human B-cell precursor adhesion to bone marrow stromal cells by cytokines that exert opposing effects on the expression of vascular cell adhesion molecule-1 (VCAM-1). Blood 1993;81: 2272-2282.

172 Ryan DH, Nuccie BL, Abboud CN, Liesveld JL: Maturation-dependent adhesion of human B cell precursors to the bone marrow microenvironment. J Immunol 1990;145:477-484.

173 Ryan DH, Nuccie BL, Abboud CN, Winslow JM: Vascular cell adhesion molecule-1 and the integrin VLA-4 mediate adhesion of human B cell precursors to cultured bone marrow adherent cells. J Clin Invest 1991;88:995-1004.

174 Rangappa S, Fen C, Lee EH, Bongso A, Sim EK: Transformation of adult mesenchymal stem cells isolated from the fatty tissue into cardiomyocytes. Ann Thorac Surg 2003;75:775-779.
175 Strem BM, Zhu M, Alfonso Z, Daniels EJ, Schreiber R, Beygui R, MacLellan WR, Hedrick $\mathrm{MH}$, Fraser JK: Expression of cardiomyocytic markers on adipose tissue-derived cells in a murine model of acute myocardial injury. Cytotherapy 2005;7:282-291.

176 Hakuno D, Fukuda K, Makino S, Konishi F, Tomita Y, Manabe T, Suzuki Y, Umezawa A, Ogawa S: Bone marrow-derived regenerated cardiomyocytes (CMG Cells) express functional adrenergic and muscarinic receptors. Circulation 2002;105 380-386.

177 Airey JA, Almeida-Porada G, Colletti EJ, Porada CD, Chamberlain J, Movsesian M, Sutko JL, Zanjani ED: Human mesenchymal stem cells form Purkinje fibers in fetal sheep heart. Circulation 2004:109:1401-1407.

178 Makino S, Fukuda K, Miyoshi S, Konishi F, Kodama H, Pan J, Sano M, Takahashi T, Hori S, Abe H, Hata J, Umezawa A, Ogawa S: Cardiomyocytes can be generated from marrow stromal cells in vitro. J Clin Invest 1999;103:697-705.

179 Shake JG, Gruber PJ, Baumgartner WA, Senechal G, Meyers J, Redmond JM, Pittenger MF, Martin BJ: Mesenchymal stem cell implantation in a swine myocardial infarct model: engraftment and functional effects. Ann Thorac Surg 2002;73:1919_ 1925; discussion 1926.

180 Mizuno H: The myogenic potential of human processed lipoaspirates - Part I: Morphological, immunohistochemical analysis and gene expression. J Japan Soc Plastic Recontr Surg 2001;21: 427-436.

181 Mizuno H, Zuk PA, Zhu M, Lorenz HP, Benhaim P, Hedrick MH: Myogenic differentiation by human processed lipoaspirate cells. Plast Reconstr Surg 2002;109:199-209; discussion 210-191.

182 Lee JH, Kemp DM: Human adipose-derived stem cells display myogenic potential and perturbed function in hypoxic conditions. Biochem Biophys Res Commun 2006:341:882-888.

183 Wakitani S, Saito T, Caplan AI: Myogenic cells derived from rat bone marrow mesenchymal stem cells exposed to 5-azacytidine. Muscle Nerve 1995; 18:1417-1426.

184 Charbord P, Lerat H, Newton I, Tamayo E, Gown AM, Singer JW, Herve P: The cytoskeleton of stromal cells from human bone marrow cultures resembles that of cultured smooth muscle cells. Exp Hematol 1990;18:276-282.

185 Galmiche MC, Koteliansky VE, Briere J, Herve P, Charbord P: Stromal cells from human long-term marrow cultures are mesenchymal cells that differentiate following a vascular smooth muscle differentiation pathway. Blood 1993;82:66-76.

186 Hicok KC, Du Laney TV, Zhou YS, Halvorsen YD, Hitt DC, Cooper LF, Gimble JM: Human adipose-derived adult stem cells produce osteoid in vivo. Tissue Eng 2004;10:371-380.

187 Justesen J, Pedersen SB, Stenderup K, Kassem M: Subcutaneous adipocytes can differentiate into bone-forming cells in vitro and in vivo. Tissue Eng 2004;10:381-391.

188 Awad HA, Butler DL, Boivin GP, Smith FN, Malaviya P, Huibregtse B, Caplan AI: Autologous mesenchymal stem cell-mediated repair of tendon. Tissue Eng 1999;5:267-277.

189 Izadpanah R, Trygg C, Patel B, Kriedt C, Dufour J, Gimble JM, Bunnell BA: Biologic properties of mesenchymal stem cells derived from bone marrow and adipose tissue. J Cell Biochem 2006;99: 1286-1297. 
190 Liu TM, Martina M, Hutmacher DW, Hoi J, Hui P, Lee EH, Lim B: Identification of common pathways mediating differentiation of bone marrow and adipose tissues derived human mesenchyma stem cells (MSCs) into three mesenchymal lineages. Stem Cells 2007;25:750-760.

191 Yoshimura H, Muneta T, Nimura A, Yokoyama A, Koga H, Sekiya I: Comparison of rat mesenchymal stem cells derived from bone marrow, synovium, periosteum, adipose tissue, and muscle. Cell Tissue Res 2007;327:449-462.

192 Musina RA, Bekchanova ES, Belyavskii AV, Sukhikh GT: Differentiation potential of mesenchymal stem cells of different origin. Bull Exp Biol Med 2006;141:147-151.

193 De Ugarte DA, Morizono K, Elbarbary A, Alfonso Z, Zuk PA, Zhu M, Dragoo JL, Ashjian P, Thomas B, Benhaim P, Chen I, Fraser J, Hedrick $\mathrm{MH}$ : Comparison of multi-lineage cells from human adipose tissue and bone marrow. Cells Tissues Organs 2003;174:101-109.

194 Kern S, Eichler H, Stoeve J, Kluter H, Bieback K: Comparative analysis of mesenchymal stem cells from bone marrow, umbilical cord blood, or adipose tissue. Stem Cells 2006;24:1294-1301.

195 Romanov YA, Darevskaya AN, Merzlikina NV, Buravkova LB: Mesenchymal stem cells from human bone marrow and adipose tissue: isolation, characterization, and differentiation potentialities. Bull Exp Biol Med 2005;140:138-143.

196 Winter A, Breit S, Parsch D, Benz K, Steck E, Hauner H, Weber RM, Ewerbeck V, Richter W: Cartilage-like gene expression in differentiated human stem cell spheroids: a comparison of bone marrow-derived and adipose tissue-derived stromal cells. Arthritis Rheum 2003;48:418-429.

197 Lee RH, Kim B, Choi I, Kim H, Choi HS, Suh K, Bae YC, Jung JS: Characterization and expression analysis of mesenchymal stem cells from human bone marrow and adipose tissue. Cell Physiol Biochem 2004:14:311-324.
198 Wagner W, Wein F, Seckinger A, Frankhauser M, Wirkner U, Krause U, Blake J, Schwager C, Eckstein V, Ansorge W, Ho AD: Comparative characteristics of mesenchymal stem cells from human bone marrow, adipose tissue, and umbilical cord blood. Exp Hematol 2005;33:1402-1416.

199 Cowan CM, Shi YY, Aalami OO, Chou YF, Mari C, Thomas R, Quarto N, Contag CH, Wu B, Longaker MT: Adipose-derived adult stromal cells heal critical-size mouse calvarial defects. Nat Biotechnol 2004;22:560-567.

200 Afizah H, Yang Z, Hui JH, Ouyang HW, Lee EH: A comparison between the chondrogenic potential of human bone marrow stem cells (BMSCs) and adipose-derived stem cells (ADSCs) taken from the same donors. Tissue Eng 2007;13:659666.

201 Hui JH, Li L, Teo YH, Ouyang HW, Lee EH: Comparative study of the ability of mesenchymal stem cells derived from bone marrow, periosteum, and adipose tissue in treatment of partial growth arrest in rabbit. Tissue Eng 2005;11:904-912.

202 Im GI, Shin YW, Lee KB: Do adipose tissue-derived mesenchymal stem cells have the same osteogenic and chondrogenic potential as bone marrow-derived cells? Osteoarthritis Cartilage 2005; 13:845-853.

203 Danisovic L, Lesný P, Havlas V, Teyssler P, Syrová Z, Kopáni M, Fujeríková G, Trc T, Syková E, Jendelová P: Chondrogenic differentiation of human bone marrow and adipose tissue-derived mesenchymal stem cells. J Appl Biomed 2007 5:139150.

204 Jeon SJ, Oshima K, Heller S, Edge AS: Bone marrow mesenchymal stem cells are progenitors in vitro for inner ear hair cells. Mol Cell Neurosci 2007;34:59-68.

205 Banas A, Teratani T, Yamamoto Y, Tokuhara M, Takeshita F, Quinn G, Okochi H, Ochiya T: Adipose tissue-derived mesenchymal stem cells as a source of human hepatocytes. Hepatology 2007;46: 219-228.
206 Sgodda M, Aurich H, Kleist S, Aurich I, Konig S, Dollinger MM, Fleig WE, Christ B: Hepatocyte differentiation of mesenchymal stem cells from rat peritoneal adipose tissue in vitro and in vivo. Exp Cell Res 2007;313:2875-2886.

207 Okumoto K, Saito T, Hattori E, Ito JI, Adachi T, Takeda T, Sugahara K, Watanabe H, Saito K, Togashi H, Kawata S: Differentiation of bone marrow cells into cells that express liver-specific genes in vitro: implication of the Notch signals in differentiation. Biochem Biophys Res Commun 2003; 304:691-695.

208 Schwartz RE, Reyes M, Koodie L, Jiang Y, Blackstad M, Lund T, Lenvik T, Johnson S, Hu WS, Verfaillie CM: Multipotent adult progenitor cells from bone marrow differentiate into functional hepatocyte-like cells. J Clin Invest 2002;109:1291-1302.

209 Kokai LE, Rubin JP, Marra KG: The potential of adipose-derived adult stem cells as a source of neuronal progenitor cells. Plast Reconstr Surg 2005;116:1453-1460.

210 Woodbury D, Schwarz EJ, Prockop DJ, Black IB: Adult rat and human bone marrow stromal cells differentiate into neurons. J Neurosci Res 2000;61: 364-370.

211 Kim BJ, Seo JH, Bubien JK, Oh YS: Differentiation of adult bone marrow stem cells into neuroprogenitor cells in vitro. Neuroreport 2002;13: 1185-1188.

212 Hermann A, Liebau S, Gastl R, Fickert S, Habisch HJ, Fiedler J, Schwarz J, Brenner R, Storch A: Comparative analysis of neuroectodermal differentiation capacity of human bone marrow stromal cells using various conversion protocols. J Neurosci Res 2006;83:1502-1514.

213 Bourin P; Gadelorge M, Peyrafitte JA, Fleuy-Cappellesso S, Gomez M, Rage C, Sensebé L: Mesenchymal stemm cells: tissue origin, isolation and culture. Transfus Med Hemother 2008;35(3): 160-167.

214 Rojewski MT, Weber BM, Schrenzenmeier H Phenotypic characterization of mesenchymal stem cells from various tissues. Transfus Med Hemother 2008;35(3):168-184 